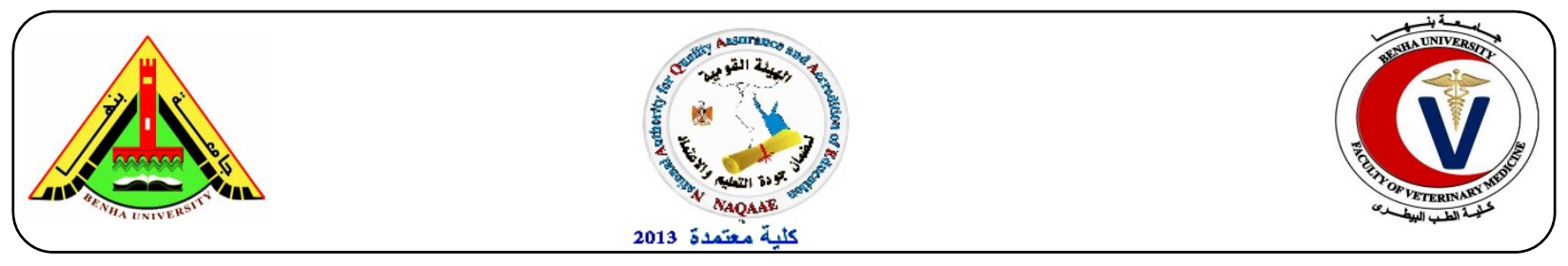

\title{
Health hazards of Aflatoxin and virulent genes of Staph aureus enterotoxins in yoghurt
}

\author{
${ }^{1}$ Dina, I. EL Zahaby; ${ }^{1}$ Shaimaa, M. Nada and ${ }^{2}$ Nermeen, H. Ghzaly. \\ ${ }^{1}$ Animal Health Research Institute, Shibin El Koom branch, Department of Food Hygiene. \\ ${ }^{2}$ Animal Health Research Institute, Shibin El Koom branch, Department of Mycology.
}

\section{A B S T R A C T}

\begin{abstract}
Eighty random samples of plain and flavored yoghurt (40of each) were collected from different supermarkets in Menoufia Governorate. The collected samples were transferred immediately to the laboratory in an icebox for mycological, bacteriological examination, estimation of aflatoxins produced by certain species of moulds and enterotoxins types A and D produced by Staph. aureus. Mould was detected in $(82.5 \%)$ of plain yoghurt samples and $(97.5 \%)$ of flavored yoghurt samples. Aspergillus and Pencillium genera were frequently detected than other genera of fungi. Aspergillus spp. were the most dominant in the contaminated samples, $(40 \%)$ in both plain and flavored yoghurt followed by Pencillium spp (30\%) of plain yoghurt and (25\%) of flavored yoghurt. Aspergillus spp. A. flavus and A. niger were the major isolates. A. flavus was isolated from plain and flavored yoghurt with apercentages of $50 \%$ and $62.5 \%$, respectively. While, A. niger was $(25 \%$ and $12.5 \%)$ from plain and flavored yoghurt, respectively. The four samples of plain yoghurt contaminated by A. flavus were analyzed for AFM1. They were positive in range from 0.049-0.472 ppb, while other four samples were free. Moreover, flavored yoghurt showed five samples contaminated with AFM1 in concentration of 0.061-0.586 ppb, while, other five samples were negative. The incidence of Staph. aureus in the collected plain and flavored yoghurt samples was $20 \%$ and $25 \%$, respectively. The average count of Staph. aureus in the examined plain and flavored yoghurt samples was $1.20 \times 10^{3} \pm 0.15 \times 10^{3}$ and $1.53 \times 10^{3} \pm 0.22 \times 10^{3} \mathrm{cfu} / \mathrm{g}$, respectively. The isolated Staph. aureus from plain and flavored yoghurt produced SEA and SED enterotoxins with a percentage of $(12.5 \%, 12.5 \%, 10 \%$ and $10 \%)$, respectively.
\end{abstract}

Keywords: Public health, Aflatoxin M1, Staph. Aureus enterotoxins

(http://www.bvmj.bu.edu.eg)

(BVMJ-28(2): 98-106, 2015)

\section{INTRODUCTION}

Plain yoghurt is the traditional type of yoghurt, while flavored yoghurt is made by addition of flavoring and sweeting agents. Yoghurt is a popular dairy product because of its beneficial influence on human health and nutritional value (Tabari et al., 2011). Aflatoxins (AFS) are secondary metabolites of fungi especially Aspergillus flavus and Aspergillus parasiticus. These moulds are common contaminants of food stuffs, particularly in the tropical regions (Gourama and Bullerman, 1995).Aflatoxin is known to be human carcinogens based on sufficient evidence of carcinogenicity in human (IARC, 1987, 1993 and Yaling et al.,
2008). Aflatoxin M1 (AFM1) may occur in milk and milk products resulted from the ingestion of Aflatoxin B1 in feed stuffs by dairy cow (Martins and Martins 2004). High performance liquid chromatography (HPLC), the analytical method employed for Aflatoxins determination is rapid, easily automatable and therefore useful for accurate screening of Aflatoxin M1 in yoghurt (Tabari et al., 2011). In the same manner, Staph. aureus is one of the most common food poisoning organism in food .The symptoms of staphylococcal food poisoning have a rapid onset (1-6 hr) and often include nausea, vomiting, diarrhea 
and abdominal pain (Jablonski and Bohach, 1997). Staph. aureus may contaminate the dairy products even in low number and this constitutes a public health hazard. The presence of Staph. aureus in milk products may be due to unhygienic handling practices, inadequate heat treatment, or faulty storage and transportation. Staph. aureus, under unfavorable condition, may lose its viability in food but might secrete enterotoxins and cause food poisoning (Erkmen, 1995). According to the biological safety, Staph. aureus is classified into risk group 2 (Human Pathogens and Toxins, 2009). That require containment lab Level 2 facilities. The enterotoxins are exoprotein, which are heat stable. Initially SEA, SEB, SEC1, SEC3, SED, and SEE were characterized (Bergdoll et al., 1973). The infective dose required to induce staphylococcal food poisoning (SFP) in humans is estimated to be around $0.1 \mu \mathrm{g}$ and it may vary with patient sensitivity (Evenson et al., 1988). The enterotoxin A is of human origin. It may contaminate milk and dairy products during different stages of production and processing or even at consumer outlet (El-Baradie, 1993). In addition, the presence of enterotoxin $\mathrm{D}$ can be attributed to the increased incidence of staphylococcal mastitis where strains of Staph. aureus were isolated from bovine mastitis and were designated as animal strains (Masud et al.,1993). Therefore, the present study was conducted to investigate the occurrence of fungi, estimation of aflatoxins produced by certain species of isolated moulds, isolation of Staph. Aureus and detection of virulent gene responsible for enterotoxins $\mathrm{A}$ and $\mathrm{D}$ production in plain and flavored yoghurt marketed in ElMenoufia Governorate, Egypt.

\section{MATERIAL AND METHODS}

\subsection{Collection of samples:}

Eighty random samples of plain and flavored yoghurt (40 of each) were collected in their original cups from some local supermarkets in Menoufia
Governorate. Collected samples were transferred immediately to the laboratory in an ice box for mycological, bacteriological examination, estimation of aflatoxins produced by certain species of moulds, Staph. aureus count and detection of virulent genes responsible for enterotoxins $\mathrm{A}$ and $\mathrm{D}$ production.

\subsection{Preparation of collected samples were carried out according to (APHA, 1992).}

\section{A. Mycological examination:}

Isolation of mould according to APHA (1992). Identification of isolated moulds according to Koneman and Roberts (1985). Aflatoxin analysis using high performance liquid chromatography (HPLC) (Technologies, Inc. 200 Regency Forset Drive, suite 330 Cary, NC 27511, USA) at Fac. Vet. Med., Benha Univ. according to AOAC (2000).

\section{B. Bacteriological examination:}

Preparation of samples and serial dilution were done for each collected samples based on the recommendation of (APHA, 1992). Enumeration and identification of Staph aureus according to FDA (2001).

\section{Detection of genes responsible for Staph. aureus enterotoxins production:}

It was made by using conventional (cPCR). PCR Master Mix used for cPCR. Oligonucleotide primers used in cPCR two pairs of primers were supplied from metabion (Germany) or Biobasic (Canada). They have specific sequence and amplify specific products. DNA Molecular weight marker. Gel Pilot 100 bp ladder (cat. no. 239035) supplied from QIAGEN. Number of bands: 6 Size range: 100-600 bp. Gel Pilot 100 bp plus ladder (cat. no. 239045) supplied from QIAGEN (USA). Number of bands: 11 Size range: 100-1500 bp. Material used for agarose gel electrophoresis. Agarose 1.5\% (Sambrook et al., 1989). Ethedium bromide solution 10 $\mathrm{mg} / \mathrm{ml}$ (Sambrook et al., 1989). Tris borate EDTA (TBE) electrophoresis buffer 
(1x) (WHO, 2002). Preparation of multiplex PCR Master Mix for Sea, Seb, $\mathrm{Sec}$ and See genes according to Emerald Amp GT PCR master mix (Takara) Code No. RR310A. Agarose gel electrophoreses (Sambrook et al., 1989) with modification.

\section{Results}

In this study table (2) showed the moulds in examined samples of yoghurt. They were highly recognized in 33 samples $(82.5 \%)$ of plain yoghurt and 39 samples $(97.5 \%)$ of flavored yoghurt, respectively. From the results obtained in Table (3), Aspergillus spp. were the most dominant in the contaminated samples $(40 \%)$ in both plain and flavored yoghurt followed by pencillium spp. (30\%) of plain yoghurt and $(25 \%)$ of flavored yoghurt, while for table (4) showed that among isolated Aspergillus spp. A.flavus and A.niger were the major isolates. A. flavus was $(50 \%$ and $62.5 \%)$ from plain and flavored yoghurt, respectively and $A$. niger was $(25 \%$ and $12.5 \%)$ from plain and flavored yoghurt. Results presented in Table (5) indicate that four samples of plain yoghurt which contaminated by A.flavus were analyzed for AFM1. They were positive in range from 0.049-0.472 ppb, while other four samples were free. While flavored yoghurt indicated, five samples were contaminated with AFM1 in concentration of 0.061-0.586 ppb while other five samples were negative. The samples which contaminated by $A$. flavus were screened by HPLC and were free of aflatoxin reflect that the presence of A. flavus does not mean the presence of mycotoxin. The results in this study failed to comply with EOSQ (2005) which stipulated that, yoghurt should be free from Pathogenic microorganisms as $A$. flavus and their aflatoxin which recorded in this study with a percentage of $40 \%$ for plain yoghurt and flavored yoghurt, respectively. As a rejected samples. On the other hand the incidence of Staph. aureus in the collected plain and flavored yoghourt samples was $20 \%$ and $25 \%$, respectively (Table 6) and the average count was $1.20 \times 10^{3} \pm 0.15 \times 10^{3}$ and 1.53 $\mathrm{x} 10^{3} \pm 0.22 \times 10^{3} \mathrm{cfu} / \mathrm{g}$, respectively. The isolated Staph. aureus from plain and flavored yoghourt produced SEA and SED enterotoxins with a percentage of $(12.5 \%$, $12.5 \%, 10 \%$ and $10 \%$ ), respectively (Table7). It is shown that the percentage of the enterotoxins were similar in plain and flavored yoghourt. The results in this study showed that the incidence of Staph. aureus in the collected plain and flavored yoghourt samples was $20 \%$ and $25 \%$, respectively, which failed to comply with EOSQ (1650 / 2005) for flavored yoghurt and (1000/ 2005) for plain yoghurt stipulated that, yoghurt should be free from pathogenic microorganisms and their enterotxins.

Table (1): Oligonucleotide primers sequences.

\begin{tabular}{|c|c|c|c|c|}
\hline Gene & Primer & $\begin{array}{l}\text { Primer sequence } \\
\qquad\left(5^{\prime}-3^{\prime}\right)\end{array}$ & $\begin{array}{l}\text { Length of } \\
\text { amplified } \\
\text { product }\end{array}$ & Reference \\
\hline Sea & $\begin{array}{l}\text { GSEAF-1 } \\
\text { GSEAR-2 }\end{array}$ & $\begin{array}{l}\text { GGTTATCAATGTGCGGGTGG } \\
\text { CGGCACTTTTTTCTCTTCGG }\end{array}$ & $102 \mathrm{bp}$ & $\begin{array}{c}\text { Mehrotraet } \\
\text { al., } 2000\end{array}$ \\
\hline
\end{tabular}

Sed

GSEDF-1

C

CAATAATAGGAGAAAATAAAAG

GSEDR-2 ATTGGTATTTTTTTTCGTTC

$278 \mathrm{bp}$ 
Table (2): prevalence of moulds in examined yoghurt samples. Samples $(n=40)$.

\begin{tabular}{ccccc}
\hline $\begin{array}{c}\text { Number of } \\
\text { examined } \\
\text { samples }\end{array}$ & \multicolumn{2}{c}{ Positive samples } & \multicolumn{2}{c}{ Negative samples } \\
$\%$ & No. & $\%$ & No. & $\%$ \\
\hline 40 & 33 & 82.5 & 7 & 17.5 \\
40 & 39 & 97.5 & 1 & 2.5 \\
\hline
\end{tabular}

Table (3): Incidence of isolated mould in the examined yoghurt. Samples $(n=40)$.

\begin{tabular}{lcccc}
\hline \multirow{2}{*}{ Isolated mould spp. } & \multicolumn{3}{c}{ Plain yoghurt } & \multicolumn{2}{c}{ Flavored yoghurt } \\
& No. & $\%$ & No. & $\%$ \\
\hline Aspergillus spp. & 16 & 40 & 16 & 40 \\
Penicillium spp. & 12 & 30 & 10 & 25 \\
Mucor spp. & 4 & 10 & 6 & 15 \\
Thamnidium spp. & 6 & 15 & 4 & 10 \\
Cladosporium spp. & 6 & 15 & 4 & 10 \\
Fusarium spp. & 2 & 5 & 4 & 10 \\
Sporotrichum spp. & 2 & 5 & 8 & 20 \\
\hline
\end{tabular}

Table (4): Incidence of examined Aspergillus spp. in relation to the positive yoghurt samples.

\begin{tabular}{lllll}
\hline Aspergillusspp & \multicolumn{2}{l}{ Plain yoghurt (16) } & \multicolumn{2}{l}{ Flavored yoghurt(16) } \\
& No. & $\%$ & No. & $\%$ \\
\hline A.flavus & 8 & 50 & 10 & 62.5 \\
A.fumigatus & 2 & 12.5 & 2 & 12.5 \\
A.niger & 4 & 25 & 2 & 12.5 \\
A.terreus & 2 & 12.5 & 2 & 12.5 \\
\hline
\end{tabular}

Table (5): Incidence and levels of (AFM1) residues in examined yoghurt samples.

\begin{tabular}{ccccccc}
\hline \multirow{2}{*}{$\begin{array}{c}\text { Types of } \\
\text { samples }\end{array}$} & No. of & \multicolumn{2}{c}{ Positive } & & \multicolumn{2}{c}{ Negative } \\
& examined & \multicolumn{2}{c}{ samples } & Range (ppb) & \multicolumn{2}{c}{ samples } \\
samples & No & $\%$ & & No & $\%$ \\
\hline $\begin{array}{c}\text { Plain yoghurt } \\
\text { Flavored }\end{array}$ & 8 & 4 & 50 & $0.049-0.472$ & 4 & 50 \\
yoghurt & 10 & 5 & 50 & $0.061-0.586$ & 5 & 50 \\
\hline
\end{tabular}




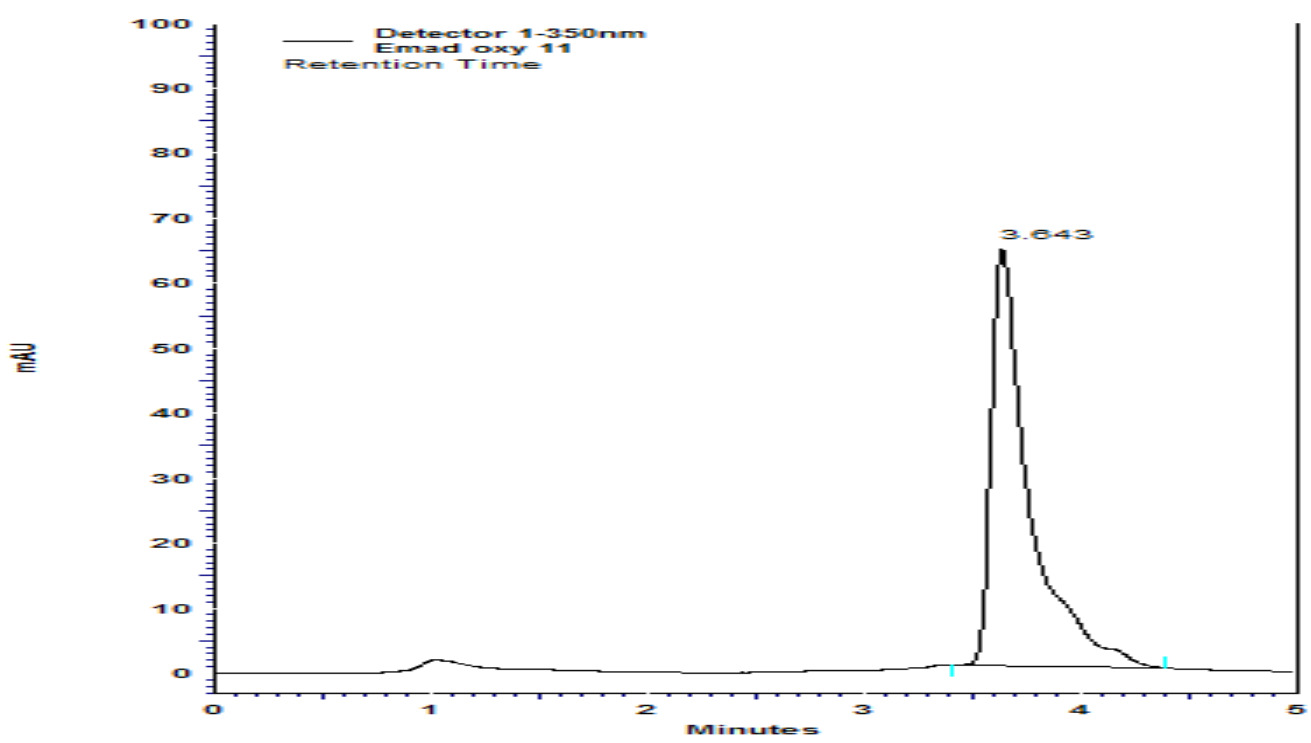

Figure (1): HPLC chromatogram of yoghurt extract for determination of aflatoxin M1 (AFM1)

Table (6): Prevalence and statistical analytical results of Staph. aureus count (cfu/g) of examined samples.

\begin{tabular}{ccccc}
\hline $\begin{array}{c}\text { Samples } \\
\text { type }\end{array}$ & $\begin{array}{c}\text { No. of } \\
\text { examined } \\
\text { samples }\end{array}$ & No. & $\%$ & Mean \pm SE \\
\hline $\begin{array}{c}\text { Plain } \\
\text { yoghurt }\end{array}$ & 40 & 8 & 20 & $1.20 \times 10^{3} \pm 0.15 \times 10^{3}$ \\
$\begin{array}{c}\text { Flavored } \\
\text { yoghurt }\end{array}$ & 40 & 10 & 25 & $1.53 \times 10^{3} \pm 0.22 \times 10^{3}$ \\
\hline
\end{tabular}

Table (7): Prevalence of virulent genes of isolated strains responsible for production of enterotoxins Types (A and D) in examined yoghurt samples.

\begin{tabular}{cccccc}
\hline \multirow{2}{*}{ Samples } & No. Of tested & \multicolumn{2}{c}{ Enterotoxin A } & \multicolumn{2}{c}{ Enterotoxin D } \\
& strains & No. & $\%$ & No. & $\%$ \\
\hline $\begin{array}{c}\text { Plain yoghurt } \\
\text { Flavored } \\
\text { yoghurt }\end{array}$ & 8 & 1 & 12.5 & 1 & 12.5 \\
\hline
\end{tabular}




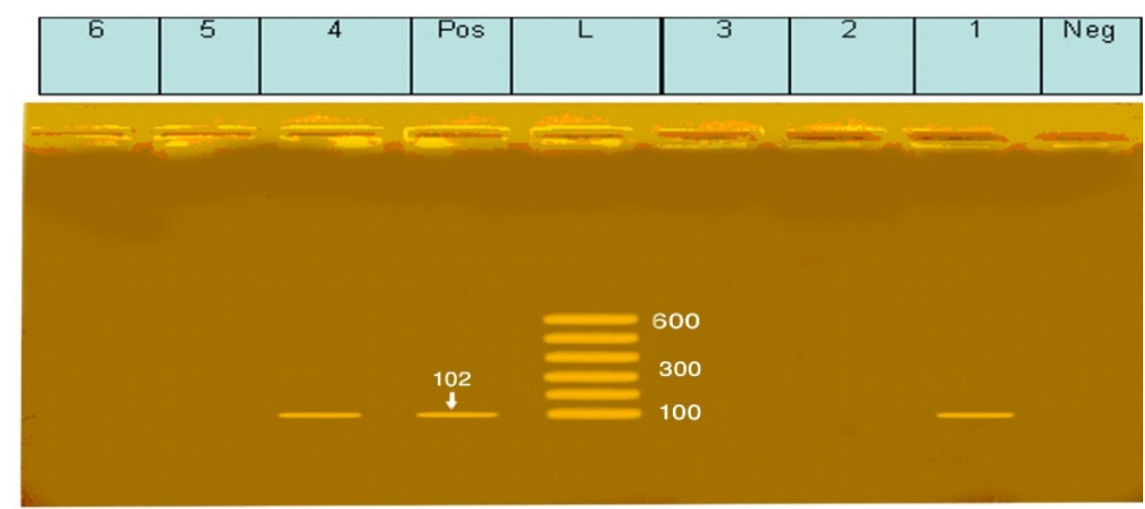

Photograph (2): Agarose gel electrophoresis of cPCR amplified of enterotoxins SEA of Staph. aureus. The genomic DNA of 6 Staph .aureus tested using specific primers for the SEA gene was amplified in $1(33.3 \%)$ Staph. aureus strains for each of plain and flavored yoghurt isolates and giving product at $102 \mathrm{bp}$. Samples $(1,2,3)$ : Plain yoghurt. Samples $(4,5,6)$ : flavored yoghurt. Lan M: 100-600 bp DNA Ladder. Pos: positive control (at 102bp). Neg: Negative control. Lane 1, 4: Staph. aureus toxin positive. Lane 2, 3, 5, 6: Staph. aureus toxin negative.

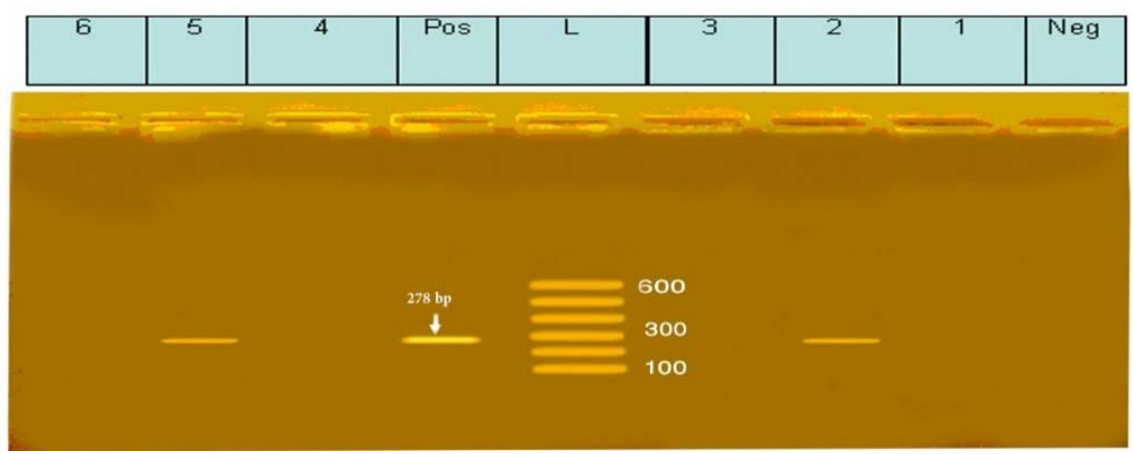

Photograph (3): Agarose gel electrophoresis of cPCR amplified of enterotoxins SED of Staph. aureus. The genomic DNA of 6 Staph. Aureus tested using specific primers for the SED gene was amplified in $1(33.3 \%)$ Staph. aureus strains for each of plain and flavored yoghurt isolates and giving product at 278bp. Samples (1, 2, 3): Plain yoghurt. Samples (4, 5, 6): flavored yoghurt. Lan M: 100-600 bp DNA Ladder. Pos: positive control (at 278bp). Neg: Negative control. Lane 1, 4: Staph. aureus toxin positive. Lane 2, 3, 5, 6: Staph. aureus toxin negative.

\section{DISCUSSION}

Moulds yoghurt was high recognized in 33 of the examined samples plain yoghurt $(82.5 \%)$ and 39 samples $(97.5 \%)$ of flavored yoghurt (table 2). These, results were similar to those obtained by Saad et al., (1987), El-Badry (1998) and Bahout and Moustafa (2003). From the results obtained in Table (3). Aspergillus spp. were the most dominant in the contaminated samples $(40 \%)$ in both plain and flavored yoghurt followed by pencillium spp. (30\%) of plain yoghurt and $(25 \%)$ of flavored yoghurt.
These results are in agreement with that reported by Marwa et al., (2013) who revealed that Aspergillus, penicillium and mucor genera were frequently detected than other genera of fungi. Table (4) showed that among isolated Aspergillus spp. A. flavus and $A$. niger were the major isolates. $A$. flavus was $(50 \%$ and $62.5 \%)$ from plain and flavored yoghurt, respectively and $A$. niger was $(25 \%$ and $12.5 \%)$ from plain and flavored yoghurt. These finding were nearly similar to those obtained by Ghazal (2001), El-Asouty (2011) and Marwa et al., (2013). Results presented in Table (5) indicated that 
four samples of plain yoghurt which contaminated by $A$. flavus were positive for AFM1. They were in range from 0.049$0.472 \mathrm{ppb}$, while other four samples were free. While flavored yoghurt indicated that five samples were contaminated with AFM1 in concentration of 0.061-0.586 ppb, while other five samples were negative. These results nearly similar with these findings reported by El-Diasty and Kaseh (2009) and Salwa (1999). The samples which contaminated by $A$. flavus were screened by HPLC and were free of aflatoxin reflect that the presence of $A$. flavus does not mean the presence of mycotoxin, that agreed with Paterson and Nelson (2010). The results in this study failed to comply with EOSQ (2005) which stipulated that, yoghurt should be free from Pathogenic microorganisms and their toxins as A. flavus and their aflatoxin which recorded in this study (8 and 10 samples)for plain yoghurt and flavored yoghurt with a percentage of 40 $\%$, respectively. On the other hand, the incidence of Staph. aureus in the collected plain and flavored yoghurt samples was $20 \%$ and $25 \%$, respectively (Table 6 ). The incidence of Staph. Aureus in yoghourt was nearly similar to those reported by Nashwa et al., (2010) and Gonui et al., (1996) but lower than those of Manal (2000), and the average count of Staph. aureus in the examined plain and flavored yoghurt samples was $1.20 \times 10^{3} \pm 0.15 \times 10^{3}$ and 1.53 $\mathrm{x} 10^{3} \pm 0.22 \times 10^{3} \mathrm{cfu} / \mathrm{g}$, respectively. This result was nearly similar to Nashwa et al. (2010) lower counts than that reported by Ahmed (1999) and Manal (2000) but higher figures than that of Dereu et al., (2004) and El- Tahiri (2005). The number of samples, which failed to comply with EOSQ (1650 / 2005) for flavored yoghurt was (10 samples) and for plain yoghurt (1000/2005) was (8samples) as it stipulated that, yoghurt should be free from pathogenic microorganisms and their enterotxins. The contamination of yoghurt with Staph. aureus could be due to lower sanitation and mishandling together with increased incidence of pathogenic staphylococcus carriers among producers (Grieger et al., 1990). Some isolates of Staph. aureus may produce enterotoxins (SEs) that cause food poisoning if sufficient amount of SEs is ingested .The enterotoxgenic strain needs to grow to levels $>10^{5} \mathrm{cfu} / \mathrm{g}$. In addition, SE formation is influenced by some parameters such as temperature, $\mathrm{pH}$, water activity, redox potential and bacterial antagonisms e.g. starter cultures used in the production of fermented milk products can prevent Staph. aureus growth and SEs production). The SEs contribute to bacterial virulence, cause emesis and may induce toxic shock (Dinges et al., 2000). The isolated Staph. aureus from plain and flavored yoghourt produced SEA and SED enterotoxins with a percentage of $(12.5 \%$, $12.5 \%, 10 \%$ and $10 \%$ ), respectively (Table7).

\section{CONCLUSION}

In conclusion, the obtained results showed high contamination of examined yoghurt samples with different types of moulds, which constitute a public health hazards due to production of their aflatoxins. Sanitary precaution with handler, utensils and the surroundings during milking and processing is essential. Moreover, the validation and verification of HACCP based procedures through the use of microbiological criteria must be high -lightened.

\section{REFERENCES}

Ahmed, E.E. 1999. Bacteriological studies on milk products. $\mathrm{PhD}$ Thesis, Fac. Of Med. of girls, AL- Azhar Univ.

Association of Official Analytical Chemists AOAC 2000. Official Methods of the AOAC International Analysis. $13^{\text {th }}$ Ed., Horwitz. W, (Editor), Academic press, Washington D.C., USA.

Bahout, A.A., Moustafa, A.H. 2003. Occurrence of fungi and Aflatoxins in yoghurt marketed in Zagazig city. Assiut Vet. Med. J. 49:96. 
Bergdoll, M.S., Robbins, R.N., Weiss, K., Borja, C.R., Huang, Y., Chu, F.S. 1973. The Staphylococcal enterotoxins similarities control. microbiol. Immunol., 1:390-396.

Dereu, K., Gruspeerdt, K., Herman, L. 2004. A Belgian survey of hygiene indicator bacteria and pathogenic bacteria in raw milk and direct marketing of raw milk from products. J. Food Safety, 24(1): 17-36.

Dinges, M.M., Orwin, P.M., Schlievert, P.M. 2000. Exotoxin of Staphylococcus aureus. Clin. Microbiol. Rev., 13(1):16-34.

El-Asouty, M.S., 2011. Mycological evaluation of some daily products with special reference to mycotoxin production. PhD thesis, Fac. Vet. Med. Alex. Univ., Egypt.

El-Badry, S.A. 1998. Sanity quality of yoghurt. M.SC. Thesis, Fac. of Vet. Med., Zagaizg Univ., Egypt.

EL-Baradie, G.A. 1993. An avidine-biotin ELISA to determine the Staphylococcal enterotoxin A in soft cheese. Alex. J. Agric. Res., 38:365378.

El-Diasty, E. Kaseh, R. 2009. Microbiological monitoring of raw milk and yoghurt samples collected from El-Beida city. Arab J. Biotech., 12(1):57-64.

EL-Tahiri, R. 2005. A comparison microbial condition between traditional dairy products sold in Karak and some products produced by modern dairies. Pakistan .J. of Nutrition, 4(5):345-348.

"Egyptian Organization for Standardization and Quality ControlEOSQ"2005. Yoghurt ES: 1000/2005, yoghurt should be free from pathogenic microorganisms and their enterotoxins.

Erkmen, O. 1995. Behavior of Staphylococcus aureusin Turkish Feta cheese manufacturing and ripening. J. Food. Protect, 58(11):1201-1205.

Evenson, M.L., Hinds, M.W., Bernstein, R.S., Bergdoll, M.S. 1988.
Estimation of human dose of Staphylococcal enterotoxin A from a large outbreak of Staphylococcal food poisoning involving chocolate milk. Int. J. Food Microbiol. 7:311-316.

FDA "Food and Drug Administration "2001: bacteriological analytical manual chapter 12 Staphylococcus aureus.

Ghazal, G.H., 2001. Mycological studies of raw milk and cheese $\mathrm{PhD}$ thesis. Fac. Vet. Med. Zagazig Univ., Egypt.

Gourama, H., Bullerman, L.B. 1995. Aspergillus flavus: aflatoxigenic fungi of cancer in foods and feed. J. food protection 58:1395-1404.

Gonui, S.A., Karapinar, M., Kargozlu, N. 1996. Microbiological quality control of delicatessen food products .Turkish J. Of Biology, 20(3):263-271.

Grieger, C., Badidova, D., Bednarcikova, E., Burdova, O., Haber, M. 1990. Detection of Staphylococcal enterotoxins in milk and milk products. Veterinari Medicina, 23(3):171-178., Dairy Sci. Abst., 53:417 (1991).

Human Pathogens, Toxins Act. 2009. Government of Canada, Second Session, Fortieth Parliament, 57-58 Elizabet II.S.C. C.24.

IARC "International Agency for Research Cancer". 1987. Monographs on the evaluation of carcinogenic risks to Humans. Overall Evaluations of carcinogenicity. Supplement 7. Lyon, France.

IARC "International Agency for Research Cancer". 1993. Monographs on the evaluation of carcinogenic risks to Humans. Some Naturally Occurring Substances: food Items and constituents, Heterocyclic Aromatic Amines and Mycotoxins 56 Lyon.

Jablonski, L.M., Bohach, G.A. 1997. Food Microbiology Fundamental and Frontiers. Dayle, M.P., Rbeuchat, L. and Montivelle, T.J. (eds), 
American Society for Microbiology Washington DC.

Koneman, E.W., Roberts, G.D. 1985. Practical Laboratory Mycology $.3^{\text {rd }}$ Ed., Williams, Baltimore, London.

Kumar, J.D., Negi, Y.K., Gaur, A., Khanna, D. 2009. Detection of virulence genes in Staphylococcus aureus isolated from paper currency. International Journal of Infectious Diseases 13: e450-e455.

Manal Ali, M.A. 2000. Studies on enterotoxigenic Staphylococci in milk and dairy products $\mathrm{PhD}$ Thesis, Fac. Vet. Med., Cairo University.

Martins, M.L., Martins, H.M. 2004. AflatoxinM1 in yoghurts in Portugal. Int. J. food Microbiol. 91(3):315-7.

Marwa, I. Khalifa, Maha, A. Al-Ashmawy, A. Abdel-khalik, M . El-Sherbini 2013. Mycological evaluation of serving some dairy products with special reference to mycotoxin production in Azhar university student hostels. World J. Dairy Food Sci., 8(2):165-170.

Masud, T., Ali, A.M., Shah, M.A. 1993. Enterotoxigenicity of Staphylococcus aureus isolated from dairy products. Australian Journal of Dairy Technol., 48(1):30-36.

Mehrotra, M., WANG, G., Johnson, W.M. 2000.Multiplex PCR for Detection of Genes for Staph. Aureus Enterotoxins, Exfoliative Toxins, Toxic Shock Syndrome Toxin 1, and Methicillin Resistance. Journal of clinical microbiology 38(3).

Nashwa, M. Abdel Atti, Hanaa, M. Sultan, Sohair, R. Bsyoni 2010. Prevalence of enterotoxigenic strains of Staphylococcus aureus in some milk products. J. Egypt Vet. Med. Assuit 10(1):57-65.

Paterson, R.R., Nelson, L. 2010. How will climate change affect mycotoxin in food. Food Research International, 43:1902-1914.

Saad, N.M., Khalil, M., Abd El-Hamied, A. 1987. Microbiological quality of yoghurt produced in Assiut city. Assiut Vet. Med. J., 19(37):87-91.

Salwa, A. Mohamed. 1999. Studies on mycotoxin in milk and some daily products. PhD thesis. Fac. of Vet. Med., Cairo Univ.

Sambrook, J., Fritscgh, E.F., Mentiates 1989. Molecular cloning. A laboratory manual. Vol. 1., Cold spring Harbor Laboratory press, New York. Method validation for Aflatoxin M1 determination in yoghurt using immune-affinity column clean up prior to high-performance liquid chromatography. Toxicol and health. 27(7):629-35.

Tabari, M., Karim, G., Ghavami, M., 2011. Method validation for aflatoxinM1 determination in yoghurt using immunoaffinity column clean -up prior to high-performance liquid chromatography. Toxical and health. 27(7):629-635.

WHO "World Health Organization" 2002. Department of communicable diseases surveillance and response.

Yaling, W., Tongjie, C., Guozhong, L., Chansons, Q., Hujyong, D., Meiling, Y., Bert-Andree.Z., Gerd, S. 2008. Simultaneous detection of airborne aflatoxin, ochratoxin and Zearalenone in poultry house by immune -affinity column and high performance liquid chromatography. Environ. Res. 107:139-144. 